\title{
Economic Effects of Winter Wheat Production on Farms in the Republic of Serbia in 2006 and 2011
}

\author{
Snežana Janković • Janja Kuzevski • Robert Radišić • \\ Sveto Rakić • Nikola Ljiljanić
}

\author{
received: 28 December 2012, accepted: 23 May 2013 \\ published online: 11 June 2013 \\ (c) 2013 IFVC \\ doi: $10.5937 /$ ratpov $50-3183$
}

\begin{abstract}
Summary: Based on the comparative analysis of gross margins in 2006 and 2011, the economic impact of winter wheat production on farms in the Republic of Serbia was estimated. The subject of the analysis was variable costs for purchased seed, fertilizers, pesticides, and contract harvesting services. Based on the analysis of the gross margin for winter wheat, it was noted that the value of production (VP), total variable costs (TVC) and gross margin (GM) were significantly higher in 2011 than in 2006. In 2011, VP was higher due to a significantly higher yield and the higher price of winter wheat grain. In addition to higher prices of all inputs, the increase in variable costs was mostly influenced by the higher price of fertilizer. Comparing the two time periods in winter wheat production, it was concluded that the value of GM in 2011 increased by $30 \%$.
\end{abstract}

Key words: agricultural economics, costs, economic analysis, gross margins, variable costs, winter wheat

\section{Introduction}

Specificity of agricultural production in the Republic of Serbia is that this production is carried out on family farms. Most of these farms are up to 3 ha in size (60\%) (Munćan \& Božić 2006). Grains are predominant crops in the sowing structure (52.2\%), above all maize followed by winter wheat (ORS, 2011).

Current problems that have been jeopardizing the development of agriculture in the Republic of Serbia were classified by Pejanović \& Kosanović (2010) into the following six groups: adverse land owning structure and non-organized farmers; unregulated market of agricultural products; uncompetitiveness; improper role of the government, demographic problems of agricultural population and the global economic crisis. In order to enforce and increase revenue and profit

S. Janković* • J. Kuzevski • R. Radišić • N. Ljiljanić

Institute for Science Application in Agriculture, Blvd. Despota Stefana $68 \mathrm{~b}$, Belgrade, Serbia

e-mail:sjankovic@ipn.co.rs

S. Rakić

University of Belgrade, Faculty of Agriculture, Nemanjina 6, BelgradeZemun, Serbia on farms with developed agricultural production, and for choosing the most profitable enterprise, various "tools" are used. Those tools can be used for evaluation of economic effects of enterprises (Lampkin et al. 2011, Popović et al. 2011, Rural Solutions SA 2012, Popescu 2012).

When it comes to field crops production, economic effects are estimated based on the achieved yields and the price of goods on the one side, and production costs on the other side. Economic effects of production for farmers doing exclusively field-crop farming are often estimated based on GM. The value of GM is different from farm to farm, depending of yield, market price, and way of selling field crops, variable costs and size of the farm. In the research of Andelić et al. (2010), it was sunflower production that had the lowest GM, due to an adverse tendency in sunflower price and input costs. Unlike this research, having analysed GM for nine most important field crop enterprises in Serbia, Janković et al. (2007) determined that winter wheat production had the lowest GM, and it

\footnotetext{
Acknowledgements:

This work has been supported by the Ministry of Education, Science and Technological Development, Republic of Serbia, Project TR 31066 "Modern breeding of small grains for recent and future needs".
} 
was mostly due to the yield, which is in accordance with the results of Anđelić et al. (2007).

Winter wheat production accounts for $30 \%$ of the entire field crops production, which can be explained as a need for optimizing sowing structure and following a crop rotation on farms (Todorović \& Munćan 2009). According to Denčić et al. (2009), sown/harvested areas in the Republic of Serbia are decreasing each year, so in 2008 , for instance, wheat was estimated to only account for $15 \%$ of the sowing structure. In the period 2000-2009, most of wheat production (78\%) was obtained on family farms (Todorović \& Filipović 2010). Considering that the human population is getting larger and wheat production needs to increase at the rate of $1.5 \%$ per year (Braun et al. 2008), it is important to increase winter wheat production in Serbia, too. Increase in production of winter wheat, traditionally produced on almost all farms in the Republic of Serbia, can be achieved through higher profitability and improved competitiveness. In order to achieve the aforementioned objectives, continuous monitoring and evaluation of economic indicators of winter wheat production are needed. Based on the analysis of economic indicators, it is possible to give recommendations and measures to ensure production profitability.

The objective was to identify and evaluate indicators that determine economic effects of winter wheat production on farms, based on the comparative analysis of GM in 2006 and 2011. In this research variable costs were analysed, namely costs of seed, fertilizers and pesticides, and contract harvesting services.

\section{Materials and Methods}

In this research, GM was used as an indicator of economic effects in winter wheat production. The basic parameters were collected through the questionnaire, and farms were chosen by selecting a random sample, having the same farm size and structure as the samples from 2006. In both years, fifty-two farms were analysed, from the territories of agricultural extension offices in Smederevo, Valjevo, Šabac, Požarevac, Jagodina, Kraljevo, Kruševac, Čačak, Loznica, Niš, Leskovac and Zaječar. The research of economic effects of enterprises from Serbian farms in 2006 and 2011 were carried out by the Institute for Science Application in Agriculture, Belgrade in collaboration with the agricultural extension offices.

The following data were used for calculations of the GM basic elements (income and expenses): yield $\left(\mathrm{kg} \mathrm{ha}^{-1}\right)$ and product market price $\left(\mathrm{RSD} \mathrm{kg}{ }^{-1}\right)$; quantity $\left(\mathrm{kg} \mathrm{ha}^{-1}\right)$ and cost of seed (RSD ha $\left.{ }^{-1}\right)$; quantity $\left(\mathrm{kg} \mathrm{ha}^{-1}\right)$ and cost of fertilizers (RSD ha $\left.{ }^{-1}\right)$; quantity $\left(1 h^{-1}\right)$ and cost of pesticides (RSD ha-1); and cost of contracted services (harvest, RSD ha-1). In reality, it is very difficult to include all the costs, having in mind limited availability of data on variable costs, therefore the research used direct variable costs for calculating GM, i.e. costs of machinery was not taken into account (Anđelić 2010). Based on these data for both years and each farmer, the following economic indicators were calculated: VP, TVC and GM. Microsoft Excel was used for processing data from farm enterprise calculations, calculating an average GM for winter wheat and elements of income and expenses. The average of each calculation element, i.e. a GM element, was envisaged to be calculated.

Based on the comparative analysis, the estimation of the production elements and economic conditions was made. The analysis of the results refers to estimating the share of variable costs and GM in total VP. The structure of variable costs (the share of costs for seed, fertilizers, pesticides and contracted services) was analysed. In the observed period, differences in gross margin elements were estimated based on the analysis of variance ( $F$ test), while regression analysis (correlation and determination coefficient) was used to estimate their impact on the gross margin.

\section{Results and Discussion}

The analysis of the collected GMs for winter wheat determined that in 2006 yields on selected farms ranged from 1500 to $7143 \mathrm{~kg} \mathrm{ha}^{-1}$, while their minimum and maximum values in 2011 ranged from $3000 \mathrm{~kg} \mathrm{ha}^{-1}$ to $6500 \mathrm{~kg} \mathrm{ha}^{-1}$. In 2011 , not only was there a significant increase in yield, but a significantly higher price of wheat grain was also noted, compared to 2006. Market price of wheat grain in 2006 ranged from $7.2 \mathrm{RSD} \mathrm{kg}^{-1}$ to $10.0 \mathrm{RSD} \mathrm{kg}^{-1}$, and in 2011 from 17.00 to 20.00 RSD kg-1. Due to the aforementioned yields and prices of winter wheat in 2011, the selected farms achieved a significant increase in VP of winter wheat. Having analysed the average values of production and other GM indicators, higher average price and yield were determined due to a significant increase in VP of winter wheat, while in 2011 there was a significant increase in TVC due to higher production costs (Table 1).

In 2011, despite higher variable costs, a higher VP led to a significantly higher GM for winter wheat than it was in 2006. That is to say, GM in 2011 was three times higher than in 2006 or 2.5 times higher when it is converted in EUR (Figure 1). 
Table 1. Basic GM indicators for winter wheat $\left(\mathrm{ha}^{-1}\right)$ on farms in the Republic of Serbia in 2006 and 2011 Tabela 1. Osnovni pokazatelji BM za ozimu pšenicu $\left(\mathrm{ha}^{-1}\right)$ na poljoprivrednim gazdinstvima u Republici Srbiji u 2006. i 2011. godini

\begin{tabular}{|c|c|c|c|c|c|c|c|}
\hline \multirow{3}{*}{ Indicator / Pokazatelj } & \multirow{2}{*}{\multicolumn{2}{|c|}{$\begin{array}{c}\text { Value in RSD Iznos u } \\
\text { RSD } \\
\text { Year / Godina }\end{array}$}} & \multirow{3}{*}{ F test ${ }^{*}$} & \multirow{2}{*}{\multicolumn{2}{|c|}{$\begin{array}{l}\text { Value in EUR } \\
\text { Iznos u EUR } \\
\text { Year / Godina }\end{array}$}} & \multirow{2}{*}{\multicolumn{2}{|c|}{$\begin{array}{l}\text { Index / Indeks } \\
\text { 2011/2006 }\end{array}$}} \\
\hline & & & & & & & \\
\hline & 2006 & 2011 & & $2006^{* *}$ & $2011^{* * *}$ & RSD & EUR \\
\hline Yield / Prinos (kg) & 4,200 & 4,713 & ** & - & - & - & - \\
\hline Price / Cena (1 kg) & 9.55 & 19.25 & ** & 0.11 & 0.19 & 201.6 & 172.7 \\
\hline $\mathrm{VP} / \mathrm{VP}$ & 40,100 & 90,750 & ** & 477 & 890 & 226.3 & 186.6 \\
\hline $\begin{array}{l}\text { VARIABLE COSTS without costs } \\
\text { contract harvesting services } \\
\text { VARIJABILNI TROŠKOVI bez } \\
\text { troškova ugovorene žetve }\end{array}$ & 14,600 & 27,854 & ** & 174 & 273 & 190.8 & 156.9 \\
\hline $\begin{array}{l}\text { Costs of contract harvesting services } \\
\text { Troškovi ugovorene žetve }\end{array}$ & 7,800 & 8,115 & ** & 93 & 80 & 104.0 & 86.0 \\
\hline TVC / UVT & 22,400 & 35,969 & ** & 266 & 352 & 160.6 & 132.3 \\
\hline $\mathrm{GM} / \mathrm{BM}$ & 17,700 & 54,781 & $* *$ & 210 & 538 & 309.5 & 256.2 \\
\hline
\end{tabular}

* Significance of differences in the observed period (years) - ${ }^{* *}=$ very significant

* Ocena značajnosti razlika za posmatrani period (godine) $-{ }^{* *}=$ veoma značajno

** $1 \mathrm{EUR}=84.15 \mathrm{RSD}$

*** $1 \mathrm{EUR}=101.97 \mathrm{RSD}$

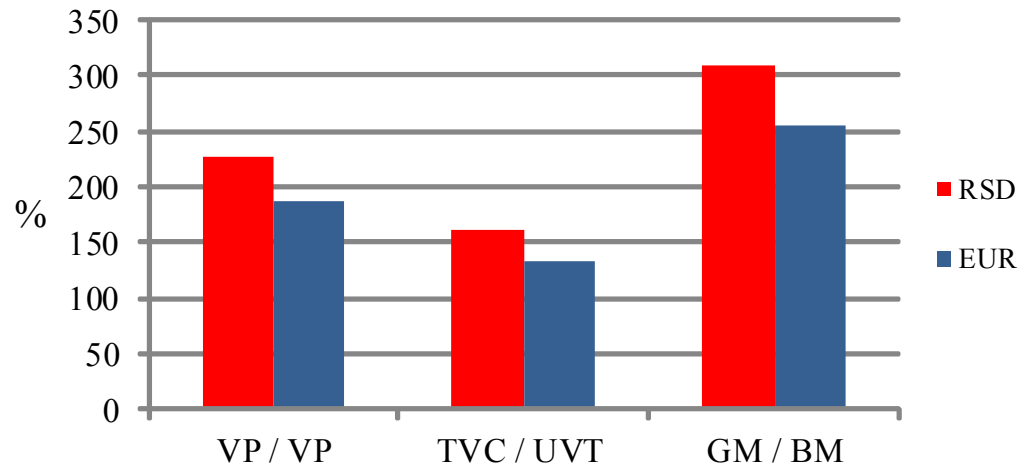

Figure 1. Increase in percentage of VP, TVC and GM in 2011, compared to 2006 (indicators calculated in RSD and foreign currency)

Graf. 1. Procentualno povećanje VP, UVT i BM u 2011. u poređenju sa 2006. godinom (dinarski i devizni obračun pokazatelja) 
Table 2. Structure of variable costs and VP of winter wheat in the Republic of Serbia, 2006 and 2011

Tabela 2. Struktura varijabilnih troškova i VP ozime pšenice u Republici Srbiji, 2006. i 2011. godina

\begin{tabular}{|c|c|c|c|c|c|c|c|c|c|c|c|}
\hline \multirow[b]{2}{*}{ Inputs / Inputi } & \multicolumn{4}{|c|}{2006} & \multicolumn{4}{|c|}{2011} & \multicolumn{3}{|c|}{ F test* } \\
\hline & $\begin{array}{l}\text { Quantity } \\
\text { Količina } \\
\text { (kg/ha) }\end{array}$ & $\begin{array}{c}\text { Price } \\
\text { Cena } \\
(\mathrm{RSD} / \mathrm{kg})\end{array}$ & $\begin{array}{c}\text { Value } \\
\text { Iznos } \\
\text { (RSD/ha) }\end{array}$ & $\begin{array}{c}\% \text { of } \\
\text { TVC } \\
\% \mathrm{u} \\
\text { UVT }\end{array}$ & $\begin{array}{l}\text { Quantity } \\
\text { Količina } \\
(\mathrm{kg} / \mathrm{ha})\end{array}$ & $\begin{array}{c}\text { Price } \\
\text { Cena } \\
(\mathrm{RSD} / \mathrm{kg})\end{array}$ & $\begin{array}{c}\text { Value } \\
\text { Iznos } \\
\text { (RSD/ha) }\end{array}$ & $\begin{array}{c}\% \text { of } \\
\text { TVC } \\
\% \mathrm{u} \\
\text { UVT }\end{array}$ & $\begin{array}{l}\text { Quantity } \\
\text { Količina }\end{array}$ & $\begin{array}{l}\text { Price } \\
\text { Cena }\end{array}$ & $\begin{array}{l}\text { Value } \\
\text { Iznos }\end{array}$ \\
\hline $\begin{array}{l}\text { Total seed Ukupno } \\
\text { seme }\end{array}$ & 307.00 & 15.27 & 4,688 & 20.8 & 272.00 & 33.79 & 9,183 & 25.5 & $* *$ & ** & ** \\
\hline NPK $(15: 15: 15)$ & 262.98 & 19.77 & 5,199 & - & 261.54 & 41.69 & 10,904 & - & & & \\
\hline Urea & 30.96 & 22.90 & 709 & - & 28.85 & 37.50 & 1,082 & - & & & \\
\hline KAN & 167.88 & 17.23 & 2,893 & - & 166.35 & 28.06 & 4,667 & - & & & \\
\hline AN & 22.60 & 16.37 & 370 & - & 17.31 & 33.78 & 585 & - & & & \\
\hline $\begin{array}{l}\text { Total fertilizers } \\
\text { Ukupno đubriva }\end{array}$ & 485.00 & 18.91 & 9,171 & 40.8 & 474.04 & 36.36 & 17,237 & 47.9 & - & ** & $* *$ \\
\hline $\begin{array}{l}\text { Total pesticides } \\
\text { Ukupno pesticida }\end{array}$ & 1.09 & 774.31 & 844 & 3.7 & 1.07 & $1,338.32$ & 1,432 & 3.9 & - & ** & $* *$ \\
\hline \multicolumn{3}{|c|}{$\begin{array}{l}\text { VARIABLE COSTS without costs of } \\
\text { contract harvesting services } \\
\text { VARIJABILNI TROŠKOVI bez troškova } \\
\text { ugovorene žetve }\end{array}$} & 14,600 & - & - & - & 2,7854 & - & & & $* *$ \\
\hline \multicolumn{3}{|c|}{$\begin{array}{l}\text { Costs of contract harvesting services } \\
\text { Troškovi ugovorene žetve }\end{array}$} & 7,800 & 34.7 & - & - & 8,115 & 22.6 & & ** & $* *$ \\
\hline \multicolumn{3}{|l|}{ TVC / UVT } & 22,400 & 100 & - & - & 35,969 & 100 & & & $* *$ \\
\hline
\end{tabular}

${ }^{*}$ Significance of differences in the observed period (years) $-{ }^{* *}=$ very significant; $--=$ non-significant

* Ocena značajnosti razlika za posmatrani period (godine) - ${ }^{* *}=$ veoma značajno; -- = nema značaja
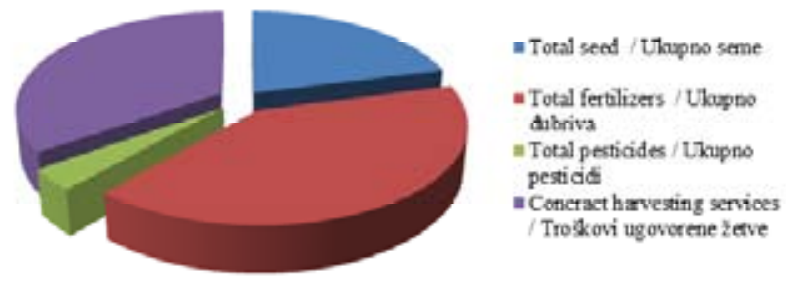

Figure 2. Structure of TVC in 2006

Graf. 2. Struktura UVT 2006. godine

Using a more detailed cost analysis for fertilizers, it was determined that in 2011 on average lower quantities of fertilizer were used, while the absolute value was due to the higher price of fertilizer (it was almost two times higher, on average). It was also ascertained that all elements of variable costs had higher prices

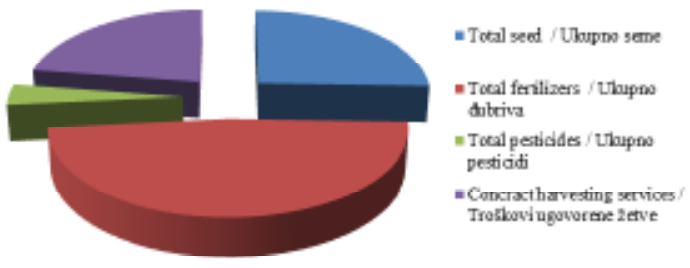

Figure 3. Structure of TVC in 2011

Graf. 3. Struktura UVT 2011. godine

than in 2006 (Table 2). Having analysed GM in the period of 2005-2009, Munćan et al. (2010) ascertained that in winter wheat production in AP Vojvodina the share of fertilizer costs was dominant in TVC. Analysing the results of this research, the dominant share of fertilizer costs in TVC was also confirmed for the entire territory of 
the Republic of Serbia. As for the other elements of variable costs, it was ascertained that the share of seed costs was slightly higher and the share of pesticide costs almost the same as in 2006, while the share of costs of contract harvesting service was lower in 2011 (Figures 2 and 3).
Based on the significance of the aforementioned indicators, in the observed period a high positive correlation was found between the yield (that is VP of winter wheat) and the GM value, while a low negative correlation was found between TVC and GM (Table 3).

Table 3. Indicators effect on the value of GM for winter wheat production on farms in the Republic of Serbia in 2006 and 2011

Tabela 3. Uticaj pokazatelja na vrednost $\mathrm{BM}$ u proizvodnji ozime pšenice na poljoprivrednim gazdinstvima u Republici Srbiji u 2006. i 2011. godini

\begin{tabular}{|c|c|c|c|c|c|c|c|c|}
\hline \multirow{4}{*}{ Indicator / Pokazatelj } & \multicolumn{4}{|c|}{2006} & \multicolumn{4}{|c|}{2011} \\
\hline & \multirow{2}{*}{ SD } & \multirow{2}{*}{$\mathrm{CV}$} & \multicolumn{2}{|c|}{$\begin{array}{l}\text { Gross margin } \\
\text { Bruto marža }\end{array}$} & \multirow{2}{*}{ SD } & \multirow{2}{*}{$\mathrm{CV}$} & \multicolumn{2}{|c|}{$\begin{array}{l}\text { Gross margin } \\
\text { Bruto marža }\end{array}$} \\
\hline & & & & & & & & \\
\hline & & & $\mathrm{r}$ & $r^{2}$ & & & $\mathrm{r}$ & $r^{2}$ \\
\hline Yield / Prinos (kg) & 967 & 23.2 & 0.82 & 0.68 & 769 & 16.3 & 0.88 & 0.77 \\
\hline Price / Cena (1 kg) & 0.4 & 4.4 & 0.35 & 0.12 & 1 & 6.6 & 0.50 & 0.48 \\
\hline $\mathrm{VP} / \mathrm{VP}$ & 9,661 & 24.2 & 0.85 & 0.73 & 16,939 & 18.7 & 0.95 & 0.90 \\
\hline $\begin{array}{l}\text { VARIABLE COSTS without costs of contr } \\
\text { harvesting services } \\
\text { VARIJABILNI TROŠKOVI bez troškova } \\
\text { ugovorene žetve }\end{array}$ & 2,657 & 18.1 & -0.02 & 0 & 4,362 & 15.4 & 0.26 & 0.07 \\
\hline $\begin{array}{l}\text { Costs of contract harvesting services } \\
\text { Troškovi ugovorene žetve }\end{array}$ & 1,668 & 21.3 & -0.18 & 0.03 & 1,431 & 13.6 & -0.17 & 0.03 \\
\hline TVC / UVT & 5,131 & 26.3 & -0.21 & 0.04 & 5,450 & 15.2 & -0.24 & 0.06 \\
\hline GM / BM & 9,310 & 45.7 & & & 17,398 & 31.8 & & \\
\hline
\end{tabular}

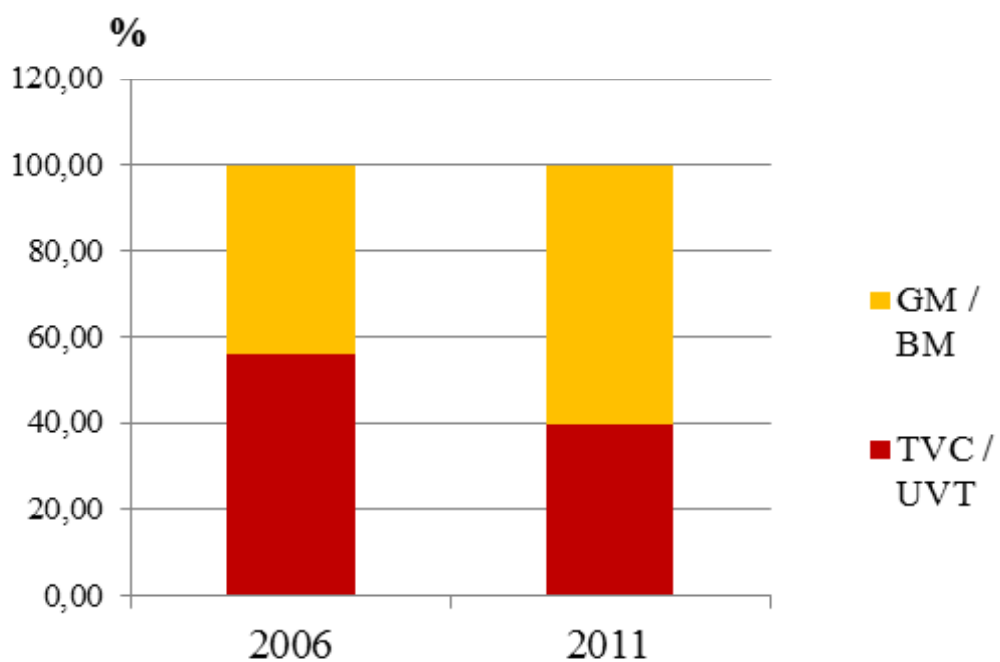

Year / Godina

Figure 4. Share of TVC in GM for winter wheat in 2006 and 2011

Graf. 4. Udeo UVT u BM za ozimu pšenicu u 2006. i 2011. godini 
For estimating economic effects of winter wheat production in the Republic of Serbia in 2006 and 2011, the analysis of the share of variable costs and GM in total VP was carried out. Considering that in 2011 the average share of variable costs (39.64\%) was lower and the share of GM higher (60.36\%) than in 2006, it can be said that economic effects of winter wheat production in 2011 were much more favourable (Figure 4).

Based on the analysis of GM for wheat production in 2006 and 2011 from the publications issued by the Chamber of Commerce of Vojvodina (in 2008 and 2012), it was determined that the share of GM in VP of wheat increased from $32.5 \%$ in 2006 to $44.8 \%$ in 2011.

Having in mind the aforementioned data and the research of Munćan et al. (2010) on the portion of GM in VP of wheat on the territory of AP Vojvodina, it can be concluded that the tendency of improving economic conditions in wheat production is the same in whole Serbia, where the portion of GM in VP accounted for $44.14 \%$ in 2006, and 60.37 in 2011.

\section{Conclusions}

Having analysed GM for farms in the Republic of Serbia, it was determined that VP, TVC and GM for winter wheat in 2011 were significantly higher than in 2006. VP was higher due to the higher yield and the price of winter wheat grain that was two times higher. The price, i.e. total cost of all inputs in 2011 was significantly higher. In 2011, the share of variable costs in total VP was lower, and the GM value increased by over $30 \%$. Comparing these two periods it was noted that farmers spent most of their money on fertilizers, and some of it on contract harvesting services. Based on this research, it can be concluded that in 2011 economic conditions for winter wheat production were much more favourable than in 2006.

\section{References}

Anđelić, B., Ivkov, I., Todorović, G., \& Milovanović, M. (2007). Gross Margin Calculation for Winter Wheat Production in Serbia during the Year 2006. In: Multifunkcionalna poljoprivreda i ruralni razvoj $u$ Republici Srpskoj, Tematski zbornik, Jahorina. p. 49.

Anđelić, B. (2010). Uticaj strukture ratarske proizvodnje na dohodak porodičnih gazdinstava. Master thesis. University of Belgrade, Faculty of Agriculture.

Anđelić, B., Janković, S., \& Tomić, V. (2010). Uticaj strukture ratarske proizvodnje na bruto maržu porodičnih gazdinstava. Poljoprivredne aktuelnosti, 1-2, 92-104.

Braun, H.J., Dixon, J., Crouch, J., \& Payne, T. (2008). Wheat research to serve the future needs of the developing world. In: Conventional and molecular breeding of field and vegetable crops, Proceedings, Novi Sad. 28-32.

Denčić, S., Kobiljski, B., Mladenov, N., \& Pržulj, N. (2009). Proizvodnja, prinosi i potrebe za pšenicom u svetu i kod nas. Zbornik radova Naućnog instituta za ratarstvo i pourtarstvo, 46(2), 367-378.

Janković, S., Goss, S., Pušić, M., Jovanović, R., Todorović, G., Tolimir, N., Ivkov, I., Anđelić, B., \& Dalton, G. (2007). Poslovanje poljoprivrednih gazdinstava u Srbiji 2006. Priručnik. Institut za primenu nauke u poljoprivredi.

Lampkin, N.H., Measures, M., \& Padel, S. (2011). Organic Farm Management Handbook, 9. Newbury: Organic Research Centre.

Munćan, P., \& Božić, D. (2006). Posedovna struktura porodičnih gazdinstava Srbije. In Poljoprivreda $i$ ruralni razvoj Srbije u tranzicionom period. Beograd: Društvo agrarnih ekonomista Srbije i Institut za agroekonomiju, Poljoprivredni fakultet.

Munćan, P., Božić, D., \& Bogdanov, N. (2010). Ekonomska efikasnost proizvodnje ratarskih kultura na porodičnim gazdinstvima u AP Vojvodini. Ekonomika poljoprivrede, 1, 15-23.

ORS. (2011). Opštine i regioni u Republici Srbiji, 2011. Beograd: Republički zavod za statistiku. Retrieved from http://webrzs.stat.gov.rs

Pejanović, R., \& Kosanović, N. (2010). Ekonomska kriza poljoprivrede Republike Srbije. Poljoprivredne aktuelnosti, 1-2, 78-91.

Popescu, A. (2012). Research regarding gross margin forecast based on average production in wheat cropping. Conference of Sustainable Rural Development. In: Lucrări Ştiințifice, Universitatea de Ştiinţe Agricole Şi Medicină Veterinară a Banatului, Seria I, 
Management Agrico. Conference of Sustainable Rural Development. International Scientific Symposium, 2012-05-25, Timişoara, Romania. 163-170.

Popović, R., Zekić, S., \& Crnobarac, J. (2011). Osnove agrarne ekonomike sa osnovama agrotehnologije. Praktikum. Subotica: Ekonomski fakultet.

Privredna komora Vojvodine (2008). Informacija o proizvodnji i tržištu pšenice i očekivanoj proizvodnji jesenjih useva roda 2008. godine u AP Vojvodini. PKV, Novi Sad.

Privredna komora Vojvodine (2012). Uslovi za ostvarivanje ratarske proizvodnje u AP Vojvodini u 2012. godini. PKV, Novi Sad.

Rural Solutions SA. (2012). A gross margin template for crop and livestock enterprises. Farm Gross Margin and Enterprise Planning Guide. By Sagit, GRCD, Rural Solutions $S A$. Government of Soth Australia.

Todorović, S.Z., \& Munćan, P. (2009). Optimiranje strukture setve porodičnih gazdinstava u nestabilnim uslovima poslovanja. Ekonomika poljoprivrede, 56(2), 329-339.

Todorović, S.Z., \& Filipović, N.S. (2010). Economic analysis of wheat production on family farms. Journal of Agricultural Sciences, 55(1), 79-87.

\title{
Ekonomski efekti proizvodnje ozime pšenice na poljoprivrednim gazdinstvima u Republici Srbiji za 2006. i 2011. godinu
}

\author{
Snežana Janković • Janja Kuzevski • Robert Radišić • Sveto Rakić • Nikola Ljiljanić
}

Izvod: Na osnovu uporedne analize vrednosti bruto marži u 2006. i 2011. godini procenjen je ekonomski efekat proizvodnje ozime pšenice na poljoprivrednim gazdinstvima u Srbiji. Analizirani su varijabilni troškovi, koji su se odnosili na utrošak novčanih sredstava za nabavku semena, đubriva, pesticida i ugovorene usluge za žetvu. Na osnovu analize kalkulacija bruto marži za ozimu pšenicu konstatovano je da su u odnosu na 2006. vrednost proizvodnje (VP), ukupni varijabilni troškovi (UVT) i bruto marža (BM) bili značajno veći u 2011. godini. U 2011. godini veća VP uslovljena je značajno većim prinosom i višom cenom zrna ozime pšenice. Na povećanje varijabilnih troškova, pored viših cena svih inputa, u najvećoj meri uticala je cena đubriva. Poređenjem ova dva vremenska perioda u proizvodnji ozime pšenice, vrednost BM u 2011. godini bila je veća za 30\%.

Ključne reči: bruto marža, ekonomska analiza, ozima pšenica, poljoprivredna ekonomija, troškovi, varijabilni troškovi 